\title{
Restoration of the habitat-forming fucoid alga Hormosira banksii at effluent-affected sites: competitive exclusion by coralline turfs
}

\author{
Alecia Bellgrove*, Prudence F. McKenzie, Jessica L. McKenzie, Bianca J. Sfiligoj
}

School of Life and Environmental Sciences, Deakin University, PO Box 423, Warrnambool, Victoria 3280, Australia

\begin{abstract}
Fucoid algae often dominate intertidal rocky shores, providing habitat and modifying ecosystem resources for other species, but are susceptible to discharge of sewage effluent. In this study we assessed the potential for competition from coralline turfs to inhibit restoration of the intertidal fucoid macroalga Hormosira banksii at sites associated with an ocean outfall a scenario of improving following water quality in the nearshore coastal environment. The percentage cover and number of individuals of $H$. banksii were negatively correlated with both the percentage cover and turf height of Corallina officinalis. In contrast, $H$. banksii was positively associated with rocky substrata and recruited well to rock-surface substrata. Importantly, there appears to be a threshold abundance where the percentage cover of $H$. banksii rarely reaches above $20 \%$ cover amongst coralline turfs with $>40 \%$ cover. These data support a model of alternative community states: H. banksii dominated canopy on rocky substrata versus $C$. officinalis turf. In field and laboratory experiments, extensive coralline turfs (up to $4 \mathrm{~cm}$ thick) were shown to inhibit recruitment of $H$. banksii. This study shows competitive exclusion by coralline turfs may limit the successful restoration of habitat provided by $H$. banksii to shores that have been affected by sustained discharge of secondarily treated sewage effluent. We suggest potential strategies for management authorities to consider when seeking ways of restoring fucoid communities affected by anthropogenic disturbances such as wastewater disposal.
\end{abstract}

KEY WORDS: Hormosira banksii - Restoration · Sewage effluent • Recruitment • Competition · Ecosystem engineer · Alternative stable states

\section{INTRODUCTION}

As the populations of coastal cities around the world continue to expand, there is increasing pressure on management authorities to more appropriately manage the disposal of domestic sewage effluent in order to reduce degradation of marine biodiversity and restore marine benthic communities to disturbed regions (Walker \& Kendrick 1998, Molloy et al. 2004). Effective rehabilitation of disturbed rocky intertidal ecosystems may result from management decisions identifying and facilitating the re-establishment of important ecosystem engineers (Jones et al. 1994, 1997; A. Bellgrove; P. F. McKenzie; J. L. McKenzie \&
J. B. Pocklington unpubl. data). Rocky intertidal reefs are often dominated by canopy-forming fucoid algae (Schiel 2004), which are often important ecosystem engineers. However, these same species are highly susceptible to anthropogenic disturbances in the nearshore coastal environment, (e.g. human trampling (Keough \& Quinn 1998, Schiel \& Taylor 1999, Araújo et al. 2009), coastal sedimentation (Amsler et al. 1992, Airoldi 2003, Schiel et al. 2006) and sewage effluent discharge (Brown et al. 1990, Fairweather 1990). In temperate Australasia, Hormosira banksii dominates much of the intertidal coastline and has many characteristics that suggest it is an important ecosystem engineer and can be negatively affected by sewage 


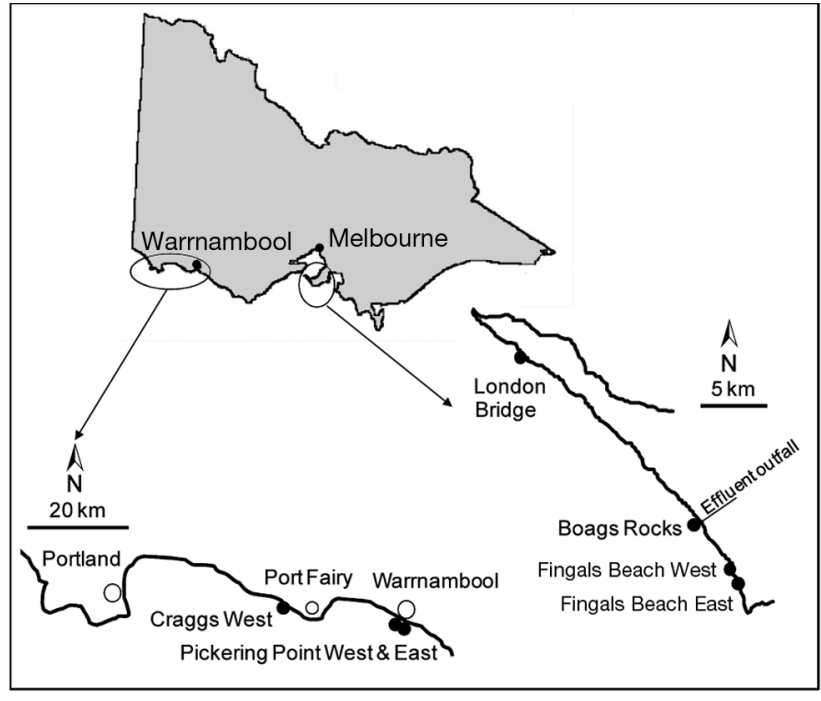

Fig. 1. Location of the study sites in Victoria, Australia. Enlargements show 4 sites on the Mornington Peninsula southeast of Melbourne and 3 sites in southwestern Victoria near the city of Warrnambool

effluent discharge (Manning 1979, Brown et al. 1990, Doblin \& Clayton 1995, Kevekordes 2000, 2001).

Melbourne, the coastal capital city of Victoria, Australia, has a population of 3.81 million (ABS 2007) and a daily sewage effluent discharge of $855 \times 10^{6} 1$ (MW 2009). Approximately $43 \%$ of Melbourne's sewage is secondarily treated and discharged below the low water mark at Boags Rocks on the Mornington Penin-

\section{Can propagules disperse from distant populations northwest of the outfall? \\ Assess dispersal potential of $H$. banksii \\ a. Supply of propagules \\ b. Genetic analysis of gene flow across broad distribution \\ c. Long distance dispersal of floating fragments}

sula (MW 2009) (Fig. 1). Hormosira banksii has disappeared completely from Boags Rocks and is greatly reduced in abundance at sites to the southeast of the outfall since the commencement of effluent discharge in 1975 (Manning 1979, Brown et al. 1990, Bellgrove et al. 1997). Ammonium and reduced salinity (due to effluent being discharged in freshwater) affect fertilisation and/or early development and survival of embryos of $H$. banksii (Doblin \& Clayton 1995, Kevekordes 2000, 2001), probably affecting successful recruitment and contributing to the decline of this species in these areas. In contrast, we have relatively little knowledge about the regenerative abilities of $H$. banksii, which can regrow from basal tissue fragments and successfully recruit from fertilised eggs into existing adult populations (Schiel \& Taylor 1999, Bellgrove et al. 2004). However, where the local populations have been completely removed, the ability of this important species to recolonise from distant undisturbed populations is unknown.

The first step to restoring effluent-affected coastlines is to improve water quality, such that pollutants are below limits of toxicity to ecosystem engineers. Upgrades to the Eastern Treatment Plant, which discharges to the ocean at Boags Rocks, are currently being undertaken to achieve advanced tertiary treatment (by the end of 2012) with ammonia and volume reductions. Assuming this can be successfully achieved, there are a number of ecological questions that need to be addressed (Fig. 2). Understanding connectivity between distant populations of Hormosira

\section{If propagules can get there, can they establish?}

Assess physical/chemical/biological interactions that exclude recruitment of $H$. banksii

a. Competitive exclusion by algal turfs

b. Rock surface structure

c. Chemical contamination of rock

d. Herbivory

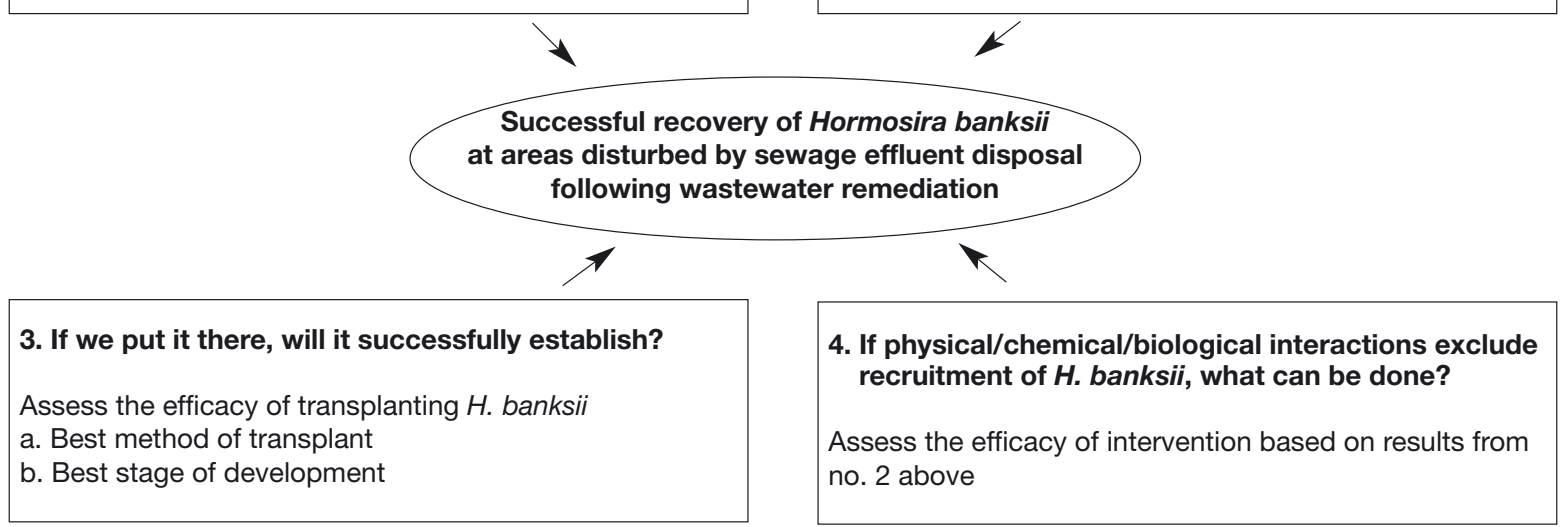

Fig. 2. Overview of the main ecological questions surrounding restoration of the habitat-forming alga Hormosira banksii at polluted shores on southeast and southwest Victoria. This study addresses point a in Box 2 (upper right) 
banksii is important to understanding whether remediated shores can be recolonised or whether algal transplants are needed. Recent studies (McKenzie \& Bellgrove 2008, 2009) suggested that $H$. banksii may be capable of infrequent long-distance dispersal via drifting fertile fragments. Successful recolonisation of $H$. banksii into remediated areas may also depend on physical, chemical and/or biological interactions. Changes in rock surface structure and rock chemistry (from sustained exposure to wastewater discharge) may negatively affect recruitment of $H$. banksii propagules. Increased grazing pressure at polluted sites (Bellgrove 1992, Firstater et al. 2010) may also negatively affect algal recruitment. Additionally, competition with the turf-forming species that currently dominate such disturbed shores may inhibit successful recruitment of $H$. banksii. In this study, we experimentally test for competitive exclusion of $H$. banksii by coralline turfs (Fig. 2, Box 2a).

Removal of canopy-forming macroalgae (e.g. Cystoseira spp.) has shown that rapid changes to the rocky shore assemblages occur, with coralline turfs often dominating (Benedetti Cecchi \& Cinelli 1992, Benedetti-Cecchi et al. 2001, Bulleri et al. 2002). Coralline turfs appear to prevent the recruitment of canopy algae to and may drive long-lasting changes community structure (Benedetti Cecchi \& Cinelli 1992, Bulleri et al. 2002). When weakened by intermediate levels of pollution, Hormosira banksii populations can decline and be replaced by articulated coralline turfs (Brown et al. 1990). Within the immediate vicinity of sewage outfalls and at intermediately polluted sites the articulated coralline alga Corallina officinalis has become abundant and, in some cases, formed extensive turfs (Borowitzka 1972, Littler \& Murray 1975, May 1985, Brown et al. 1990, Bellgrove et al. 1997). Articulated coralline algae (e.g. C. officinalis) and fucoid canopies (e.g. H. banksii) are potentially alternative stable states (Petraitis \& Latham 1999). We tested hypotheses associated with the model that $H$. banksii assemblages and coralline turfs are alternative stable states where the coralline turfs are maintained by exclusion of successful recruitment of $H$. banksii propagules through structural aspects of the turf.

\section{MATERIALS AND METHODS}

Study sites. All study sites were intertidal rock platforms of dune limestone/sandstone conglomerates on the Mornington Peninsula, southeastern Victoria, and in southwestern Victoria near the city of Warrnambool, Australia (38 $23^{\prime} \mathrm{S}, 142^{\circ} 28^{\prime}$ E) (Fig. 1). The Mornington Peninsula has a southwesterly aspect and is exposed to the weather conditions of Bass Strait, with prevailing southwesterly winds and associated high swells (for a more detailed description of this area see Brown et al. 1990, Povey \& Keough 1991). The study area in southwestern Victoria has a more southerly aspect and is exposed to the weather conditions of the Southern Ocean with similarly prevailing southwesterly winds and associated high swells. Approximately $43 \%$ of Melbourne's sewage effluent is secondarily treated at the South Eastern Purification Plant and discharged at Boags Rocks $\left(38^{\circ} 30^{\prime} \mathrm{S}, 144^{\circ} 53^{\prime} \mathrm{E}\right.$; Fig. 1) at approximately $370 \times 10^{6} \mathrm{l} \mathrm{d}^{-1}$. Sites southeast of the outfall at Fingals Beach East and West (Cape Schanck from Bellgrove et al. 1997) have exhibited community changes since discharge commencement (Brown et al. 1990), indicative of intermediate pollution effects. Sites northwest of the outfall are apparently unpolluted (Brown et al. 1990). In southwestern Victoria, Pickering Point East and West (Fig. 1) are in the Merri Marine Sanctuary and approximately $2 \mathrm{~km}$ southeast of the Warrnambool secondarily treated sewage effluent outfall (discharging approx. $10 \times 10^{6} \mathrm{ld}^{-1}$ ). Without historical data it is impossible to know whether these sites have been affected by the effluent, but the algal assemblages are similar to those at Fingals Beach with extensive coralline turfs and patchy areas of Hormosira banksii; we called these impacted sites. The Craggs West is located approximately $10 \mathrm{~km}$ west of Port Fairy, is unaffected by sewage effluent and is infrequently disturbed by recreational activities.

Competition with coralline turfs. To test the hypothesis that Hormosira banksii recruits and established plants would be more abundant on rocky substrata than amongst turfs, thirty 100-point quadrats, $0.25 \mathrm{~m}^{2}$ in size, were haphazardly sampled at similar tidal heights at each of 2 unimpacted sites (London Bridge, The Craggs West) and 4 impacted sites (Fingals Beach East and West, Pickering Point East and West) representing the spectrum of variability amongst sites from very high abundance of $H$. banksii through to very high abundance of Corallina officinalis (Fig. 1). Sampling was conducted on 8, 15 and 22 November 2005. At each site, we surveyed 15 quadrats to examine the relationship between coralline turf and $H$. banksii by recording percentage covers of $H$. banksii and $C$. officinalis, number of individuals (distinct clumps) of $H$. banksii and the height of the coralline turf. We surveyed a further 15 quadrats to examine the relationship between $H$. banksii and rocky substrata, where we recorded the percentage covers of $H$. banksii and rocky substrata, and the number of individuals of $H$. banksii.

We further hypothesised that zygotes of Hormosira banksii that are seeded into turf substrata (real or artificial) will not survive and develop as well as those seeded onto rocky substrata (i.e. structural exclusion). 
To test this hypothesis, field and laboratory experiments were conducted in mid-April 2005. The laboratory and field experiments had the same experimental design with 10 replicates of each of 3 treatments: coralline turf, artificial turf and rock. We hypothesised that if it is the structure of the turf alone that inhibits recruitment of Hormosira banksii, recruitment to the artificial turf should be similar to that of the coralline turf. Because of high mortality in pilot field trials, molluscan exclusion fences of copper-painted zincalume ant caps were placed beneath each of the panels in the field experiment to exclude herbivorous molluscs (Bellgrove 1998). All panels had exclusion fences so any potential artefact of the fences was consistent amongst treatments.

Artificial substrata $(10 \times 10 \mathrm{~cm})$ were used to facilitate microscopic examination of zygotes. For the rock treatment we used rock mimics that have similar recruitment of Hormosira banksii as do natural rock surfaces (Bellgrove 1998, Bellgrove et al. 2004). Rock mimics were constructed from clear polyester resin cast from moulds of rock surfaces (Bellgrove et al. 2004); turf mimics were constructed from $4 \mathrm{~mm}$ synthetic grass (Sundeck \#601, Ideal Distributers) embedded in $\sim 200 \mathrm{ml}$ clear polyester resin; dead cleared coralline turf substrata were constructed from $10 \times$ $10 \mathrm{~cm}$ pieces of dense Corallina officinalis turf that had been oven-dried at $60^{\circ} \mathrm{C}$ for $24 \mathrm{~h}$ to kill turf and infauna (removed with forceps) and embedded in $\sim 200 \mathrm{ml}$ resin. Because natural recruitment of $H$. banksii is low and variable (Bellgrove et al. 1997, 2004), we artificially seeded our experimental units and assessed survival and development. Experimental units were seeded in the laboratory with $10 \mathrm{ml}$ of $H$. banksii zygote solution, prepared from ten $15 \mathrm{~cm}$ female fronds and three $15 \mathrm{~cm}$ male fronds (ratios compatible with preventing polyspermy, Kevekordes \& Clayton 1996). The zygote solution was gently dispensed over the surface of the wetted panels and then cultured in microfiltered (0.22 $\mu \mathrm{m}$; Sterivac Millipore) seawater to rhizoid initiation stage (approx. $48 \mathrm{~h}$, Kevekordes \& Clayton 1996) at $15^{\circ} \mathrm{C}$ on a $12 \mathrm{~h}$ light: $12 \mathrm{~h}$ dark cycle to improve attachment strength and reduce mortality through dislodgement (Taylor \& Schiel 2003) observed in pilot trials. For the field experiment, 10 replicates of each treatment were set up (as in Bellgrove et al. 2004) at The Craggs West site. Panels were retrieved $14 \mathrm{~d}$ after initial seeding and examined with the aid of a dissecting microscope for zygote survival and development.

A parallel laboratory experiment was simultaneously conducted using the same design (excluding molluscan exclusion fences) to examine recruitment of Hormosira banksii under no-flow conditions, maximising the chance for attachment (Taylor \& Schiel 2003).
Experimental panels were all cultured in individual clear plastic containers filled with microfiltered seawater at $15^{\circ} \mathrm{C}$ on a $12 \mathrm{~h}$ light: $12 \mathrm{~h}$ dark cycle, and randomised within controlled temperature cabinets.

Statistical analyses. Survey data were analysed by linear regression. Laboratory and field experimental data were analysed for germling survival with 1-way ANOVA with 3 levels (coralline turf, artificial turf, rock) in the treatment factor (fixed). Assumptions of normality and homogeneity of variances were checked with box plots and residual plots. Tukey's Honestly Significant Difference (HSD) pairwise comparisons compared all treatments after ANOVA on data from the competitive exclusion experiments. Experimental data were 4 th-root transformed to improve normality and homogeneity of variances.

\section{RESULTS}

\section{Competition with coralline turfs}

There was a significant negative relationship between the percentage cover of Corallina officinalis and that of Hormosira banksii $(y=-0.561 x+57.044, p<$ 0.001; Fig. 3a). Conversely, there was a significant positive relationship between the amount of rocky substrata and the percentage cover of $H$. banksii ( $y=$ $0.533 x+1.514, \mathrm{p}<0.001$; Fig. 3b). Additionally, these relationships both explained about $60 \%$ of the variability in the data $\left(r^{2}=0.59\right.$ and 0.61 , respectively). The same patterns were seen for the number of individuals of $H$. banksii and cover of $C$. officinalis and rock (data not shown). Similarly, there was a significant negative relationship between the height of the coralline turf and both the percentage cover and number of individuals of $H$. banksii $(y=-0.957 x+29.587, p<0.001, y=$ $-0.496 x+16.599 ; \mathrm{p}<0.001$, respectively; Fig. 3c,d), but in this case the relationships only explained about $20 \%$ of the variability in the data $\left(r^{2}=0.19\right.$ and 0.18 , respectively) indicating that there are characteristics of the turfs other than just height that influence the abundance of $H$. banksii.

Importantly, there appears to be a threshold abundance where the percentage cover of Hormosira banksii rarely reaches above $20 \%$ cover amongst coralline turfs with $>40 \%$ cover (Fig. 3a). This is typically the case for impacted shores (Fig. 3a). Where Corallina officinalis cooccurs at $<40 \%$ cover with $H$. banksii, it is usually a sparsely branched understorey inhabitant. Beyond $40 \%$ cover, C. officinalis generally forms more densely branched and tight turfs. Similarly, $H$. banksii is rarely abundant amongst turfs $>30 \mathrm{~mm}$ in height, but highest abundances occur where turfs are $<10 \mathrm{~mm}$ high (Fig. 3c,d). 

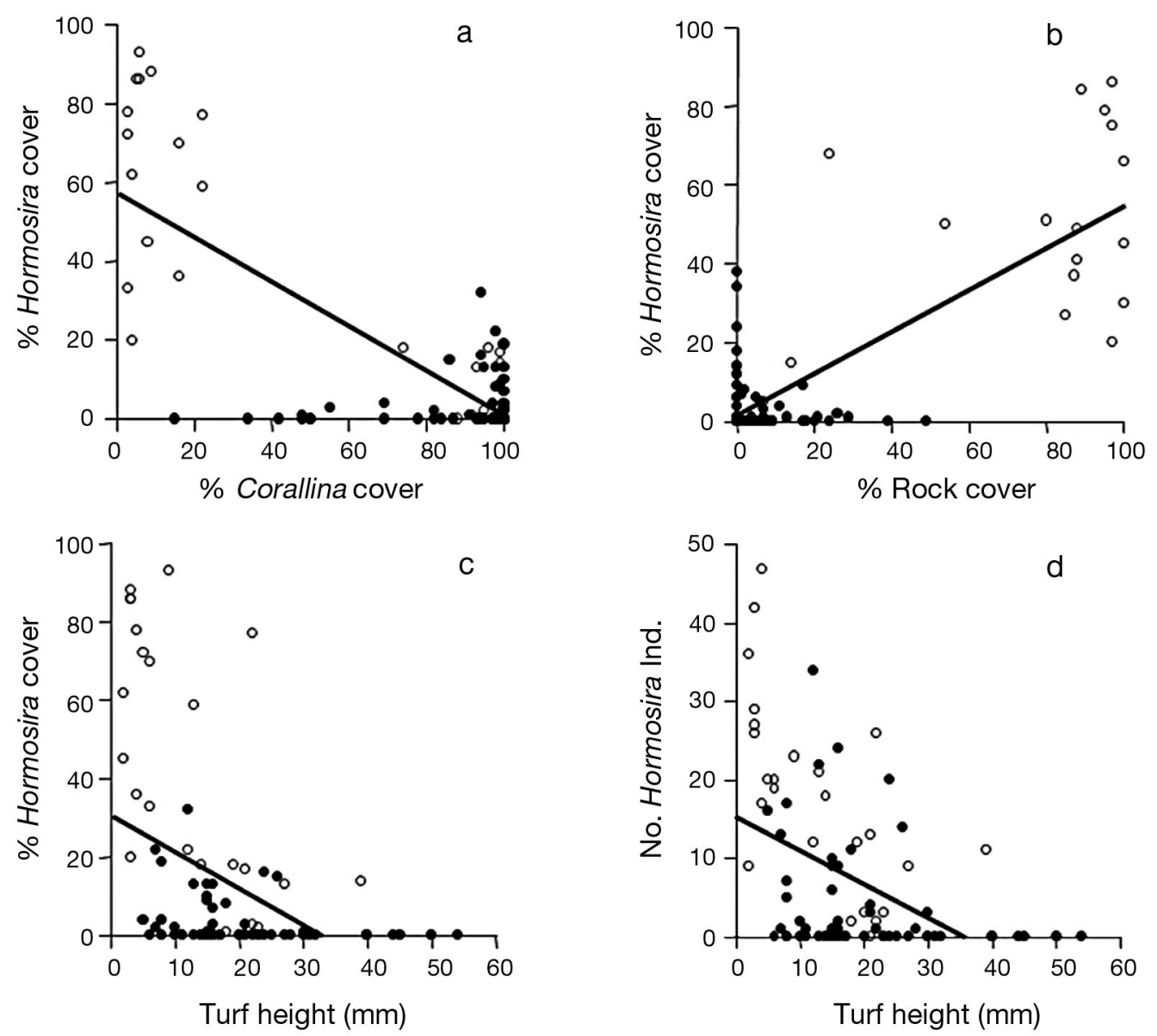

Fig. 3. Hormosira banksii. Relationships between percentage covers of the fucoid macroalga and (a) Corallina officinalis, (b) rock, (c) turf height of $C$. officinalis, and (d) between number of $H$. banksii individuals and $C$. officinalis turf height. (O) unimpacted shores (•) impacted shores

Both the natural (coralline) and artificial turf substrata had fewer germlings of Hormosira banksii remaining after $2 \mathrm{wk}$ in the laboratory and the field compared with the rock substrata (Fig. 4). For the laboratory experiment, this was statistically significant (treatment: $F_{2,27}=289.184, \mathrm{p}<0.001$, Tukey's test $\mathrm{p}<0.001$ for all comparisons; Table 1 ), although in the field experiment the heterogeneous variances, because of large numbers of zeros on the turf substrata, meant the data could not be analysed. However, the pattern is the same (Fig. 4). Additionally, in the laboratory experiment germling densities were significantly lower in the natural coralline turf treatment compared with the artificial turf treatment, although both were low (Tukey's test $\mathrm{p}<0.001$; Fig. 4a). It is also noteworthy that although there were treatment effects, mortality in the field was high across all treatments ( $y$-axis scales in Fig. 4b vs. Fig. 4a).

\section{DISCUSSION}

As the percentage cover of Corallina officinalis increases, both the percentage cover and number of individuals of Hormosira banksii decreases. However, there appears to be a threshold cover where the percentage cover of $H$. banksii rarely reaches above $20 \%$ amongst coralline turfs with $>40 \%$ cover. In contrast, $H$. banksii was positively associated with rocky substrata and recruited well to rock-surface substrata. These data support a model of alternative community states: $H$. banksii dominated canopy on rocky substrata versus $C$. officinalis turf. While we propose that the 'switch' from a $H$. banksii canopy to coralline turf involves an anthropogenic disturbance, carefully planned experiments are needed to test for the origin of these potential alternate states (Petraitis \& Latham 1999, Petraitis \& Dudgeon 2004). Similarly, Benedetti Cecchi \& Cinelli (1992) suggested that Cystoseira 

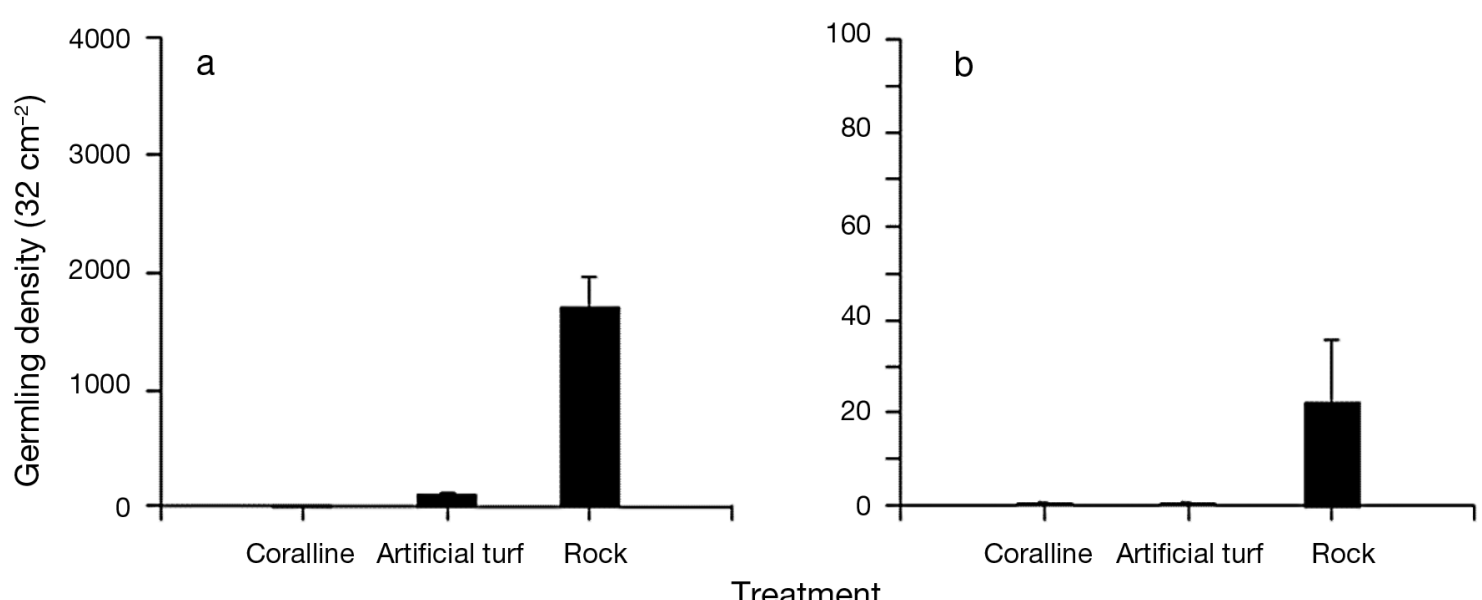

Treatment

Fig. 4. Hormosira banksii. Mean ( \pm SE) germling density (no. germlings $32 \mathrm{~cm}^{-2}$ ) on experimental substrata of Corallina officinalis turf, artificial turf and rock mimics after $2 \mathrm{wk}$ in (a) the laboratory under controlled conditions (see text for description) and

(b) the field under natural conditions

Table 1. Hormosira banksii. Results of 1-way ANOVA and post-hoc Tukey's HSD test comparing the survival of germlings amongst treatments (coralline turf, artificial turf and rock) after $2 \mathrm{wk}$ in the laboratory experiment. $\mathrm{N}=10$

\begin{tabular}{lrrrrc|}
\hline Source & SS & df & MS & F-ratio & $p$ \\
\hline Treatment & 161.945 & 2 & 80.972 & 289.184 & $<0.001$ \\
Error & 7.560 & 27 & 0.280 & & \\
Coralline vs. artificial & & & & $<0.001$ \\
Coralline vs. rock & & & & $<0.001$ \\
Artificial vs. rock & & & & & $<0.001$ \\
\hline
\end{tabular}

canopies and articulated coralline turfs could represent alternative stable states (also linked to anthropogenic disturbance in the Mediterranean Sea, Benedetti-Cecchi et al. 2001), but again stressed the need for more detailed analysis of the origins and stability of these states. This study demonstrates, however, that these turf assemblages may be maintained, at least in part, by competitive exclusion of $H$. banksii recruits through some aspect associated with the structure of $C$. officinalis turfs.

Our data show that Hormosira banksii was rarely abundant amongst turfs $>30 \mathrm{~mm}$ in height, but highest abundances occur where turfs are $<10 \mathrm{~mm}$. However, it is important to note that turf height only explained about $20 \%$ of the variability in the cover and number of individuals of $H$. banksii. In New Zealand, Schiel \& Taylor (1999) found that $H$. banksii could only recruit to coralline turfs that had been reduced to $<2 \mathrm{~mm}$ in height (by human trampling). Turf height is likely to interact with a number of other factors (such as sedimentation and water flow) that may influence recruitment of $H$. banksii.
Algal turfs have been suggested for several decades to inhibit intertidal macroalgal recruitment (Hruby \& Norton 1979, Sousa 1979, Keser \& Larson 1984, Benedetti Cecchi \& Cinelli 1992, Schiel \& Taylor 1999, Bulleri et al. 2002), but the mechanisms have been rarely explicated (Worm \& Chapman 1998). A turf of Chondrus crispus was found to inhibit the growth of germlings and juveniles of Fucus evanescens but could not exclude established $F$. evanescens germlings unless combined with grazing pressure (Worm \& Chapman 1998). Growth inhibition was suggested to be due to reduced light levels $(2 \pm 0.2 \%$ ambient $)$ below the turf canopy (Worm \& Chapman 1998). Dense algal canopies can reduce the amount of light reaching the understorey and thereby limit the growth of understorey algae (Reed \& Foster 1984). Indeed, growth of other fucoids (F. vesiculosus, F. serratus and Ascophyllum nodosum) can be depressed by dense canopies (McCook \& Chapman 1991, Jenkins et al. 1999). We may expect that long turfs are likely to shade the substratum more than shorter turfs and therefore have a stronger negative effect on recruits of Hormosira banksii. However, Santelices et al. (2002) found that propagules from a wide range of macroalgal taxa germinated in either very low light ( 2 to $10 \mu \mathrm{mol} \mathrm{m} \mathrm{m}^{-2} \mathrm{~s}^{-1}$ ) or complete darkness, independent of phylogeny, life history, size or successional status. They concluded that most macroalgal propagules and microscopic forms are able to withstand extended periods of darkness or dim light, and reiterated that germination may depend on stored energy reserves rather than photosynthesis (Clayton 1992, Reed et al. 1992). It therefore seems unlikely that the effects of turfs observed over the $2 \mathrm{wk}$ duration of the experiments in this study are due to reduced light level within the turfs. 
During the relatively short duration of the field experiment, we observed significant accumulation of sand in all replicates of both the coralline and artificial turf substrata. This is consistent with studies that have shown turfing algae to accumulate and stabilise sediments (reviewed in Airoldi 2003). The microscopic stages of fucoid algae can be vulnerable to the effects of sediment (Amsler et al. 1992, Airoldi 2003, Schiel et al. 2006). In particular, Schiel et al. (2006) showed that even a light dusting of sediment could reduce settlement of Hormosira banksii by $34 \%$ and heavy sedimentation could prevent settlement entirely. Additionally, even short-term burial of $H$. banksii germlings could result in $100 \%$ mortality (Schiel et al. 2006). In view of the work by Santelices et al. (2002), it seems most likely that these smothering effects are due to abrasion of recently settled propagules or sediment chemistry (Chapman \& Fletcher 2002, Airoldi 2003) rather than reduced light levels (Airoldi 2003). Although we have not measured it, it is probable that longer turfs could trap more sand, and therefore possibly impose a greater smothering pressure, than do shorter turfs. While there is significant evidence that sand accumulation and the associated effects of an unstable substratum for attachment, i.e. abrasion and anoxia, are detrimental to the early life stages of macroalgae and $H$. banksii in particular (Neushul et al. 1976, Emerson \& Zedler 1978, Bellgrove et al. 1997, Chapman \& Fletcher 2002, Schiel et al. 2006), this alone cannot explain the negative effects of turfs on recruitment of $H$. banksii seen in this study. We observed strong treatment effects in both laboratory and field experiments, yet only the field experiments were exposed to sand accumulation. While there was much higher mortality in the field experiment than in the laboratory, which could potentially be attributed in part to sedimentation, mortality was also high for the rock treatment that accumulated only small amounts of sediment.

It has been suggested that recruitment of fucoid algae may be enhanced in red algal turfs because reduced wave motion facilitates strong zygote attachment and/or the turf structure traps dislodged embryos (Brawley \& Johnson 1991). Zygotes of Hormosira banksii require long periods of calm conditions for secure attachment (Taylor \& Schiel 2003). Thus, knowledge of the time of release of propagules is important for understanding the interactions between turf structure, hydrodynamics and zygote attachment. $H$. banksii begins to release gametes on exposure to air as the tide begins to recede such that gametes are visible on the thalli early in the low tide period (A. Bellgrove pers. obs.). Many of these gametes appear to slip off the wet thalli into the puddles remaining beneath adult plants (Bellgrove et al. 1997, J. L. McKenzie \&
A. Bellgrove unpubl. data). While propagules of $H$. banksii were rarely found in the water column (Bellgrove et al. 1997, 2004) more intensive temporal sampling suggests that they do make it into the water column more frequently than previously thought (J. L. McKenzie \& A. Bellgrove unpubl. data). However, a large proportion of successful recruitment into established adult habitats (Bellgrove et al. 2004) probably occurs very early in the low tide, allowing for maximum time for adhesion (Taylor \& Schiel 2003). If this is the case, the ability for coralline turfs to reduce water velocities is probably not important for facilitating zygote attachment of $H$. banksii (c.f. Brawley \& Johnson 1991).

In contrast, the negative effects of surface tension between fronds of the turfing algae may be very important. As the tide recedes, algal turfs typically hold water and potentially provide refugia from the desiccating effects of emersion (Hay 1981, Brawley \& Johnson 1991, 1993, Kelaher et al. 2001). However, in densely clumped turfs there is also notable surface tension between fronds of both natural and artificial turfs (A. Bellgrove pers. obs.). The small ( 64 $\mu$ m diameter) zygotes of Hormosira banksii may be held above the substratum by this surface tension and prevented from attaching during low tide. They may then be removed with the incoming tide washing over the turfs. Artificial seeding of $H$. banksii zygotes onto the substrata used in field and laboratory experiments during this study was done simulating our present understanding of maximum release and settlement during the early stage of emersion (see above). Thus, the substrata were wet but not submerged in filtered seawater during seeding. Therefore, surface tension between fronds inhibiting attachment of zygotes of $H$. banksii is a plausible explanation for the results seen in both field and laboratory experiments in this study. A future study could further assess differences in surface tension with height of the algal turfs and the effects on recruitment of $H$. banksii. Theoretically there should be a turf height at which the effects of surface tension are negligible, perhaps related to the turf-height limits for successful recruitment of $<10 \mathrm{~mm}$ as seen in this study or $<2$ mm observed by Schiel \& Taylor (1999).

We have been unable to test models of biological exclusion in this study due to unexplained high mortality across all treatments in the field (experiments not presented). Although our results clearly demonstrate a negative effect of turf structure on the recruitment of Hormosira banksii, we cannot rule out an additional influence of biological exclusion. Coralline turfs are known to support a diverse assemblage of macrofauna (Kelaher et al. 2001, Kelaher 2002, Chapman et al. 2005) and it may be expected that at least some species may consume macroalgal propagules. While generally 
fucoid algae are an unpalatable food source (Schoenwaelder 2002), the propagules and young germlings, which have lower phenolic contents and less complex cell walls (Schoenwaelder \& Clayton 1998), may be more vulnerable to herbivory than are their older counterparts (Lubchenco 1983). Additionally, several species of nongeniculate and geniculate coralline algae, including Corallina pilulifera, can have multiple allelopathic activity against settlement and germination of a diverse range of macroalgal propagules, microalgae and invertebrate larvae (Suzuki et al. 1998, Jeong et al. 2000, Kim et al. 2004, Kitamura et al. 2005). The active algicidal products in C. pilulifera remained stable when boiled and exposed to light (Jeong et al. 2000). If similar products are present in C. officinalis, it is possible that our methods of killing the algae before embedding them in the resin did not destroy these toxic compounds. An additional effect of toxicity in coralline turf substrata over the structural exclusion observed for artificial turfs may explain the significant differences observed in $H$. banksii recruitment to the 2 turf substrata in the laboratory experiment. Coralline algae can also reduce epiphyte loads by sloughing off epithallus cell layers (Johnson \& Mann 1986, Littler \& Littler 1999), and it is possible that this may also inhibit recruitment of $H$. banksii into the coralline turfs.

\section{Implications for habitat restoration of polluted shores}

Results of this study clearly show that coralline turfs can inhibit recruitment of Hormosira banksii. We conclude that the extensive turfs (up to $4 \mathrm{~cm}$ thick) of Corallina officinalis at sites southeast of the Boags Rocks outfall (Brown et al. 1990) are very likely to inhibit re-establishment of $H$. banksii, even if water quality was conducive to early development and growth. Alternate stable states are often resistant to restoration efforts because of positive feedbacks that maintain the state (Irfanullah \& Moss 2004, Troell et al. 2005, Young et al. 2005). This study shows that restoring the $H$. banksii habitat and associated species at southeastern sites (e.g. Fingals Beach) is only likely to be achieved by clearing turfs to provide suitable amounts of rocky substrata for recruitment of $H$. banksii. However, before such clearings are undertaken it is essential that we have a better understanding of the appropriate size of clearings that will facilitate recolonisation of $H$. banksii (e.g. providing escapes from edge effects) and whether this will result in a switch back to a $H$. banksii-dominated habitat (Petraitis \& Latham 1999). Additionally, it is essential that we understand the importance of an adult canopy of $H$. banksii to the successful recruitment of propagules of this species. This knowledge can only be gained by carefully planned manipulative experiments. It is also important to remember that there are other factors that may also influence successful habitat restoration (Fig. 2), and it is essential that we gain a better understanding of these factors to successfully manage restoration efforts.

Acknowledgements. We thank J. Pocklington for field assistance and C. Grace for accommodation during fieldwork. Discussions with B. Robson influenced the design of aspects of this study. We thank B. Light for early discussions in framing the project and Melbourne Water and Parks Victoria for access to study sites. This project was funded by the Environment Protection Authority (EPA) Victoria. Research within the Port Phillip Heads Marine National Park and Merri Marine Sanctuary were conducted under permits \#10003479 and \#10003066, respectively.

\section{LITERATURE CITED}

ABS (Australian Bureau of Statistics) (2007) 3235.0 - Population by age and sex, regions of Australia, 2007; Victoria. Australian Bureau of Statistics, Belconnen ACT

Airoldi L (2003) The effects of sedimentation on rocky coast assemblages. Oceanogr Mar Biol Annu Rev 41:161-236

Amsler CD, Reed DC, Neushul M (1992) The microclimate inhabited by macroalgal propagules. Br Phycol J 27: $253-270$

> Araújo R, Vaselli S, Almeida M, Serrão E, Sousa-Pinto I (2009) Effects of disturbance on marginal populations: human trampling on Ascophyllum nodosum assemblages at its southern distribution limit. Mar Ecol Prog Ser 378:81-92

Bellgrove A (1992) The effects of effluent discharge at Boags Rocks IV. Results of monitoring programme 1980-1992: macroalgae. Technical Report. Melbourne Water, Melbourne

Bellgrove A (1998) Recruitment of intertidal macroalgae on a wave-exposed rocky coast. PhD thesis, Monash University, Clayton

Bellgrove A, Clayton MN, Quinn GP (1997) Effects of secondarily treated sewage effluent on intertidal macroalgal recruitment processes. Mar Freshw Res 48:137-146

Bellgrove A, Clayton MN, Quinn GP (2004) An integrated study of the temporal and spatial variation in the supply of propagules, recruitment and assemblages of intertidal macroalgae on a wave-exposed rocky coast, Victoria, Australia. J Exp Mar Biol Ecol 310:207-225

Benedetti Cecchi L, Cinelli F (1992) Canopy removal experiments in Cystoseira-dominated rockpools from the Western coast of the Mediterranean (Ligurian Sea). J Exp Mar Biol Ecol 155:69-83

Benedetti-Cecchi L, Pannacciulli F, Bulleri F, Moschella PS, Airoldi L, Relini G, Cinelli F (2001) Predicting the consequences of anthropogenic disturbance: large-scale effects of loss of canopy algae on rocky shores. Mar Ecol Prog Ser 214:137-150

Borowitzka MA (1972) Intertidal algal species diversity and the effect of pollution. Aust J Mar Freshw Res 23:73-84

> Brawley SH, Johnson LE (1991) Survival of fucoid embryos in the intertidal zone depends upon developmental stage and microhabitat. J Phycol 27:179-186

Brawley SH, Johnson LE (1993) Predicting desiccation stress in microscopic organisms: the use of agarose beads to determine evaporation within and between intertidal 
microhabitats. J Phycol 29:528-535

Brown VB, Davies SA, Synnot RN (1990) Long-term monitoring of the effects of treated sewage effluent on the intertidal macroalgae community near Cape Schanck, Victoria, Australia. Bot Mar 33:85-98

Bulleri F, Benedetti-Cecchi L, Acunto S, Cinelli F, Hawkins SJ (2002) The influence of canopy algae on vertical patterns of distribution of low-shore assemblages on rocky coasts in the northwest Mediterranean. J Exp Mar Biol Ecol 267:89-106

Chapman AS, Fletcher RL (2002) Differential effects of sediments on survival and growth of Fucus serratus embryos (Fucales, Phaeophyceae). J Phycol 38:894-903

Chapman MG, People J, Blockley D (2005) Intertidal assemblages associated with natural corrallina turf and invasive mussel beds. Biodivers Conserv 14:1761-1776

> Clayton MN (1992) Propagules of marine macroalgae: structure and development. Br Phycol J 27:219-232

> Doblin M, Clayton MN (1995) Effects of secondarily treated sewage effluent on the early life history stages of two species of brown macroalgae: Hormosira banksii and Durvillaea potatorum. Mar Biol 122:689-698

Emerson SE, Zedler JB (1978) Recolonization of intertidal algae: an experimental study. Mar Biol 44:315-324

Fairweather PG (1990) Sewage and the biota on seashores: assessment of impact in relation to natural variability. Environ Monit Assess 14:197-210

Firstater FN, Hidalgo FJ, Lomovasky BJ, Tarazona J, Flores G, Iribarne OO (2010) Coastal upwelling may overwhelm the effect of sewage discharges in rocky intertidal communities of the Peruvian coast. Mar Freshw Res 61:309-319

> Hay ME (1981) The functional morphology of turf-forming seaweeds: persistence in stressful marine habitats. Ecology 62:739-750

Hruby T, Norton TA (1979) Algal colonization on rocky shores in the Firth of Clyde. J Ecol 67:65-77

Irfanullah H, Moss B (2004) Factors influencing the return of submerged plants to a clear-water, shallow temperate lake. Aquat Bot 80:177-191

> Jenkins SR, Hawkins SJ, Norton TA (1999) Direct and indirect effects of a macroalgal canopy and limpet grazing in structuring a sheltered inter-tidal community. Mar Ecol Prog Ser 188:81-92

> Jeong JH, Jin HJ, Sohn CH, Suh KH, Hong YK (2000) Algicidal activity of the seaweed Corallina pilulifera against red tide microalgae. J Appl Phycol 12:37-43

> Johnson CR, Mann KH (1986) The crustose coralline alga, Phymatolithon foslie, inhibits the overgrowth of seaweeds without relying on herbivores. J Exp Mar Biol Ecol 96: $127-146$

Jones CG, Lawton JH, Shachak M (1994) Organisms as ecosystem engineers. Oikos 69:373-386

> Jones CG, Lawton JH, Shachak M (1997) Positive and negative effects of organisms as physical ecosystem engineers. Ecology 78:1946-1957

Kelaher BP (2002) Influence of physical characteristics of coralline turf on associated macrofaunal assemblages. Mar Ecol Prog Ser 232:141-148

Kelaher BP, Chapman MG, Underwood AJ (2001) Spatial patterns of diverse macrofaunal assemblages in coralline turf and their associations with environmental variables. J Mar Biol Assoc UK 81:917-930

Keough MJ, Quinn GP (1998) Effects of periodic disturbances from trampling on rocky intertidal algal beds. Ecol Appl 8:141-161

Keser M, Larson B (1984) Colonization and growth dynamics of three species of Fucus. Mar Ecol Prog Ser 15:125-134

Kevekordes K (2000) The effects of secondary-treated sewage effluent and reduced salinity on specific events in the early life stages of Hormosira banksii (Phaeophyceae). Eur J Phycol 35:365-371

> Kevekordes K (2001) Toxicity tests using developmental stages of Hormosira banksii (Phaeophyta) identify ammonium as a damaging component of secondary treated sewage effluent discharged into Bass Strait, Victoria, Australia. Mar Ecol Prog Ser 219:139-148

Kevekordes K, Clayton M (1996) Using developing embryos of Hormosira banksii (Phaeophyta) as a marine bioassay system. Int J Plant Sci 157:582-585

Kim J, Choi JS, Kang SE, Cho JY, Jin HJ, Chun BS, Hong YK (2004) Multiple allelopathic activity of the crustose coralline alga Lithophyllum yessoense against settlement and germination of seaweed spores. J Appl Phycol 16: 175-179

Kitamura M, Koyama T, Nakano Y, Uemura D (2005) Corallinafuran and corallinaether, novel toxic compounds from crustose coralline red algae. Chem Lett 34:1272-1273

Littler MM, Littler DS (1999) Epithallus sloughing: a selfcleaning mechanism for coralline algae. Coral Reefs 18:204

Littler MM, Murray SN (1975) Impact of sewage on the distribution, abundance and community structure of rocky intertidal macro-organisms. Mar Biol 30:277-291

> Lubchenco J (1983) Littorina and Fucus: effects of herbivores, substratum heterogeneity, and plant escapes during succession. Ecology 64:1116-1123

Manning PP (1979) The biological effects of the discharge of secondarily treated sewage effluent at Boags Rocks, Gunnamatta Beach, Victoria. MSc thesis, La Trobe University, Melbourne

May V (1985) Observations on algal floras close to two sewerage outlets. Cunninghamia 1:385-394

McCook LJ, Chapman ARO (1991) Community succession following massive ice-scour on an exposed rocky shore: effects of Fucus canopy algae and mussels during late succession. J Exp Mar Biol Ecol 154:137-169

> McKenzie PF, Bellgrove A (2008) Dispersal of Hormosira banksii (Phaeophyceae) via detached fragments: reproductive viability and longevity. J Phycol 44:1108-1115

> McKenzie PF, Bellgrove A (2009) Dislodgment and attachment strength of the intertidal macroalga, Hormosira banksii (Fucales, Phaeophyceae). Phycologia 48:335-343

Molloy R, Fox D, Stauber J, Beardall J (2004) Eastern Treatment Plant: monitoring and receiving environment. Commonwealth Scientific and Industrial Research Organisation, Melbourne

MW (Melbourne Water) (2009) Sewage treatment-today. Melbourne Water, Melbourne

Neushul M, Foster MS, Coon DA, Woessner JW, Harger BWW (1976) An in situ study of recruitment, growth and survival of subtidal marine algae: techniques and preliminary results. J Phycol 12:397-408

> Petraitis PS, Dudgeon SR (2004) Detection of alternative stable states in marine communities. J Exp Mar Biol Ecol 300: 343-371

> Petraitis PS, Latham RE (1999) The importance of scale in testing the origins of alternative community states. Ecology 80:429-442

Povey A, Keough MJ (1991) Effects of trampling on plant and animal populations on rocky shores. Oikos 61:355-368

Reed DC, Foster MS (1984) The effects of canopy shading on algal recruitment and growth in a giant kelp forest. Ecology 65:937-948

Reed DC, Amsler CD, Ebeling AW (1992) Dispersal in kelps: factors affecting spore swimming and competency. Ecology 73:1577-1585 
Santelices B, Aedo D, Hoffmann A (2002) Banks of microscopic forms and survival to darkness of propagules and microscopic stages of macroalgae. Rev Chil Hist Nat 75: $547-555$

Schiel DR (2004) The structure and replenishment of rocky shore intertidal communities and biogeographic comparisons. J Exp Mar Biol Ecol 300:309-342

Schiel DR, Taylor DI (1999) Effects of trampling on a rocky intertidal algal assemblage in southern New Zealand. J Exp Mar Biol Ecol 235:213-235

Schiel DR, Wood SA, Dunmore RA, Taylor DI (2006) Sediment on rocky intertidal reefs: effects on early post-settlement stages of habitat-forming seaweeds. J Exp Mar Biol Ecol 331:158-172

Schoenwaelder MEA (2002) The occurrence and cellular significance of physodes in brown algae. Phycologia 41:125-139

Schoenwaelder MEA, Clayton MN (1998) Secretion of phenolic substances into the zygote wall and cell plate in embryos of Hormosira and Acrocarpia (Fucales, Phaeophyceae). J Phycol 34:969-980

Sousa WP (1979) Experimental investigations of disturbance and ecological succession in a rocky intertidal algal community. Ecol Monogr 49:227-254

Editorial responsibility: Lisandro Benedetti-Cecchi, Pisa, Italy
Suzuki Y, Takabayashi T, Kawaguchi T, Matsunaga K (1998) Isolation of an allelopathic substance from the crustose coralline algae, Lithophyllum spp., and its effect on the brown alga, Laminaria religiosa Miyabe (Phaeophyta). J Exp Mar Biol Ecol 225:69-77

Taylor DI, Schiel DR (2003) Wave-related mortality in zygotes of habitat-forming algae from different exposures in southern New Zealand: the importance of 'stickability'. J Exp Mar Biol Ecol 290:229-245

Troell M, Pihl L, Ronnback P, Wennhage $\mathrm{H}$, Soderqvist $\mathrm{T}$, Kautsky N (2005) Regime shifts and ecosystem services in Swedish coastal soft bottom habitats: when resilience is undesirable. Ecol Soc 10:U606-U618

> Walker DI, Kendrick GA (1998) Threats to macroalgal diversity: marine habitat destruction and fragmentation, pollution and introduced species. Bot Mar 41:105-112

Worm B, Chapman ARO (1998) Relative effects of elevated grazing pressure and competition from a red algal turf on two post-settlement stages of Fucus evanescens C. Ag. J Exp Mar Biol Ecol 220:247-268

Young T, Petersen D, Clary J (2005) The ecology of restoration: historical links, emerging issues and unexplored realms. Ecol Lett 8:662-673

Submitted: April 3, 2009; Accepted: September 23, 2010

Proofs received from author(s): November 23, 2010 